\title{
Water environmental protection in craft villages of Vietnam
}

\author{
Nguyen Khanh Bui1 ${ }^{1, *}$ \\ ${ }^{1}$ Graduate Academy of Social Science, 477, Nguyen Trai Str., 10000, Hanoi, Vietnam
}

\begin{abstract}
Craft villages are a unique feature of rural Vietnam. They play an important role in rural social - economic development and contribute to industrialisation and modernisation processes. Craft village development contributes to poverty alleviation and hunger eradication in rural areas, provides jobs in leisure time, improves incomes and quality of life etc. However, the sustainable development of craft villages has yet to receive due attention from legislation and administrative authorities at all levels. Unlike many countries in the world, craft villages in Vietnam are not only associated with the preservation of cultural values but also exist as industrial clusters. Based on traditional activities, craft villages of Vietnam are characterized by small-scale level, manually operated equipment and backward technologies, low material/fuel efficiency, suffered limitations of manufacturing space and possessed insufficient awareness on environment and health protection of the people. Because of this, a number of the activities of the craft villages have imposed pressure on their respective environments, and the surrounding communities, especially water environmental pollution. This article focuses on the challenges of water environmental protection in craft villages of Vietnam; It also provides shortcomings in water environmental management in craft villages and recommendation to amend and supplement regulations and mechanisms related to water environmental management in craft villages in Vietnam.
\end{abstract}

\section{Introduction}

Craft villages are one of the unique features of Vietnam's rural areas. In craft villages, a number of non-agricultural products are produced by farmers and placed on the market as commercial goods so that household living standards could be improved and leisure time could be made use of. Most craft villages have evolved over hundreds of years along with the social economic, cultural, and agricultural development of the country. For example, the Dai Bai copper casting village (Bac Ninh) has had 900 years of history, 500 years for Bat Trang pottery village (Hanoi) and 400years for both Dong Xam carving village (Thai Binh) and Non Nuoc rock sculpture village (Da Nang). In the past, craft villages were not only the centers of handicraft production but were also the cultural centres of the region (MONRO, 2008).

The development of "craft villages" boomed in 1990s, just after the beginning of Doi

*Corresponding author: khanhlaw75@yahoo.com 
Moi process, when the government untied the private sector for economic activities (Hai H.T., Quang N.D., Thang N.T., Nam N.H. (2020). In recent years, craft villages have changed rapidly due to the economic transition towards a market economy and the encouragement of home craft production for domestic use and export. The industrialization trend and the promulgation of policy that creates a favorable environment for the development of home craft production have increased the incomes of rural households and promoted the employment of modern technologies. In addition, the development of new craft villages and groups of craft villages has been encouraged for rural development, employment, and sustainable incomes (MONRO, 2008).

Based on Art. 3 and Art. 4 of Government's Decree No. 52/2018/ND-CP dated April 12, 2018 on development of rural trade, "craft villages" means one or a number of residential clusters being a small villages, mountain village, hamlet or similar residential area engages in the rural trades such as: (i) Processing and preserving agriculture, forestry and aquatics/fisheries products; (ii) Production of hand-made products; (iii) Treatment and processing of raw materials serving production by rural trades; (iv) Production of funiture, bamboo and rattan, ceramics, glass, tetxtiles, yam, embroidery, knitting and small-scale mechanical products; (v) Production and trading of animals as pets; (vi) Salt mining; (vii) Services serving rural production and the lives of citizens in rural areas.

Traditional craft village means a craft village engaged in traditional crafts which have been formed over along period of time: (i) the traditional craft has been in the locality for more than fifty (50) years and is currently continuing to be developed up until the time of the request for recognition; (ii) The traditional crafts create products with national cultural traits; (iii) The traditional craft is associated with the name of none or more artisans or with name of the craft village. Unlike many countries in the world, craft villages in Vietnam are not only associated with the preservation of cultural values but also exist as industrial clusters.

Up to December 2018, according to the new criteria, there were only 2,009 craft villages officially recognized in Vietnam (including 1,134 craft villages and 875 traditional craft villages). The environmental protection obligations of craft villages are stipulated in Circular

No. 46/2011/TT-BTNMT providing for the environmental protection of craft villages and Circular No. 31/2016/TT-BTNMT dated October 14, 2016, providing for Environmental protection for industrial clusters, concentrations of business, service providers, craft villages, production commercial and service establishments (MONRE 2020).

Based on traditional activities, craft villages of Vietnam are characterized by small-scale level backward technology, equipment and skills. They lead to material and fuel overconsumption, increased pollutant emission to water, soil and air, and affects product prices and environmental quality. Craft villages have applied manual and semi-mechanical techniques. None of the craft villages has applied automatic techniques (MONRO 2008). Because of this, a number of the activities of the craft villages have imposed pressure on their respective environments, and the surrounding communities, especially water environmental pollution.

According to the results of the survey and assessment of the Ministry of Natural Resources and Environment (MONRE), the water environmental protection in craft villages still faces many shortcomings. The implementation of water environmental protection in craft villages in some localities showed that many craft villages have not been invested in construction of recycle waste water infrastructure; causing adverse impacts on the environment landscape, causing air, water and soil pollution. Many craft villages produce traditional food, recycle scrap (paper, plastic, metal ...) which have caused a large amount of solid waste after the production process. This waste is not collected and treated but 
discharged directly into public areas, ponds, lakes, causing clogging of drainage systems, serious pollution of surface water, underground water (MONRO 2020).

Based on practical results of management and implementing the regulations related to

water environmental management in craft villages, in Vietnam shows that besides some positive results (Vietnam Law and Legal Forum (2015), the mechanism management and legal framework for water environmental protection in craft villages of Vietnam has revealed the shortcomings and limitations, which need to be amended and supplemented to resolve the current environmental challenges in Vietnam.

This review was developed by discussing challenges of water environmental protection in craft villages of Vietnam, focus mainly in shortcomings and limitations of management and implementing the regulations related to water environmental protection in craft villages of Vietnam with the data and supported by Ministry of Natural Resources and Environment (MONRE) and Environment and Natural Resources Department of Provinces in Vietnam.

\section{Materials and Methods}

This paper discusses literature review as a methodology and is based on published data of Vietnam Environment Administration, Ministry of Natural Resources and Environment (MONRE) and Environment and Natural Resources Department of Provinces in Vietnam from 2014-2019. Based on legal and public management approach, this paper uses the comparison and analysis methods to analyze and compares mechanism management, the provisions of laws related to water environmental protection in craft villages of Vietnam and practical implementation of such regulations. The water environment in the craft villages mentioned in this article includes surface water and ground water.

It shall be noted that environmental data collected mainly official information, omitting an undefined number of pending cases for further investigation. Neither skills, equipment nor integrity variables were available and taken into account for this article.

\section{Results}

\subsection{The challenges of water environmental protection in craft villages of Vietnam}

Water pollution in the river basins has not been improved, the problem of inundation in cities tends to expand and increase. In most river basins, there are environmental pollution spots with different pollution levels. Many parts of the river have been prolonged pollution such as the pollution of Nhue river, To Lich river in Hanoi City, Ngu Huyen Khe river in Bac Ninh; a system of flowing canals. through Districts 8, Binh Chanh, Hoc Mon (Ho Chi Minh City) .... Besides, a new hot spot on water environment pollution (the Chau Giang river section, the Bac Hung Hai river system, ...). The main reason is due to untreated or unsatisfactory discharge of wastewater sources from craft villages, industrial zones production facilities, domestic wastewater, services in urban areas and wastewater from mining activities at the headwaters have polluted surface water sources. 


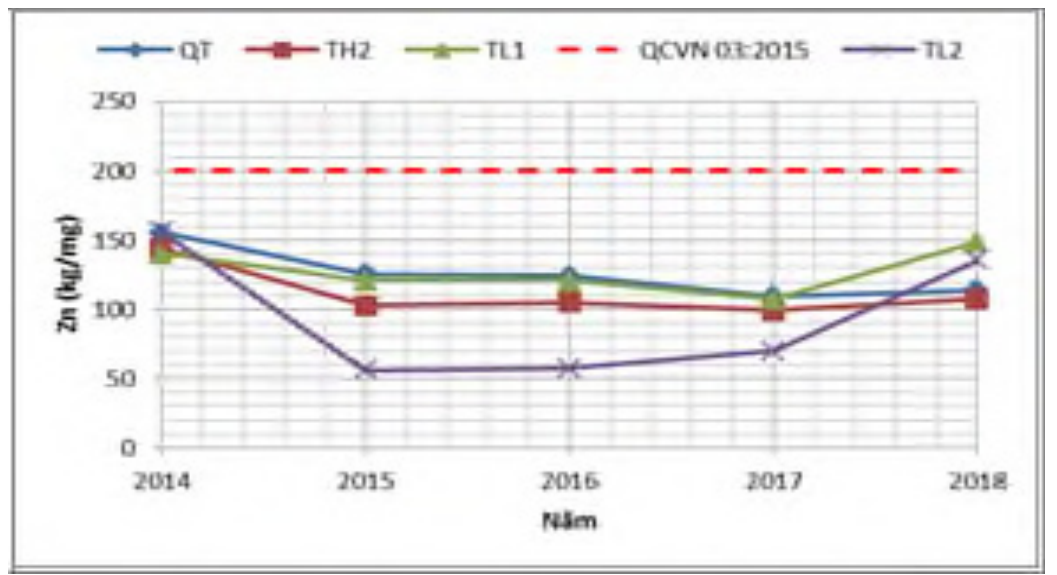

Fig. 1. WQI ((Water Quality Index) value ratio at the monitoring points in river basins in Vietnam during 2014-2018 (Source: Vietnam Environment Administration, Ministry of Natural Resources and Environment, 2019) (MONRE 2020).

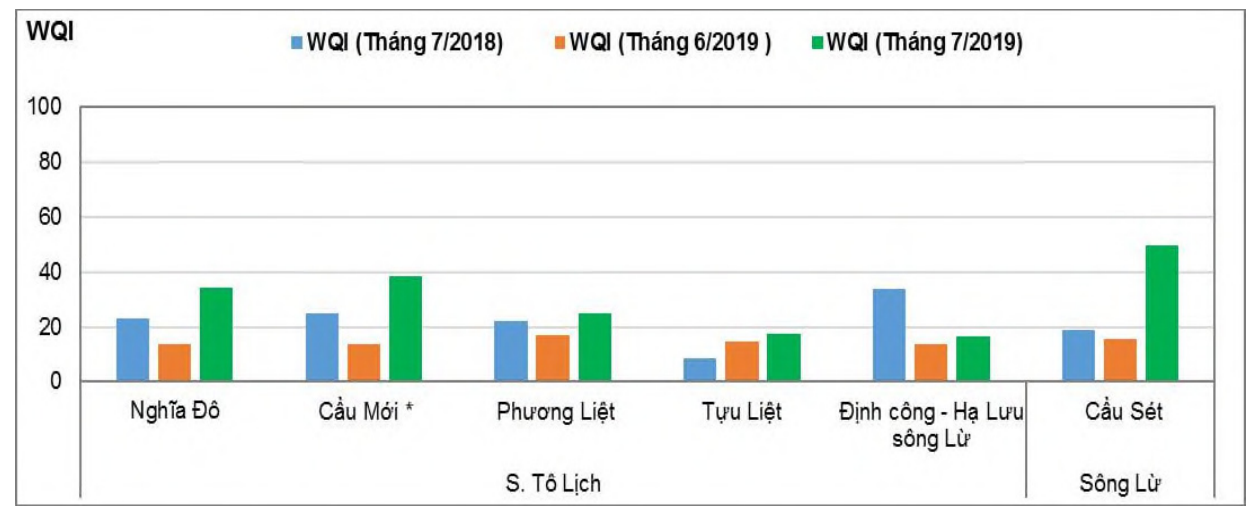

Fig. 2. WQI (Water Quality Index) value ratio at the monitoring points in rivers in Hanoi during 2018-2019 (Source: Vietnam Environment Administration, Ministry of Natural Resources and Environment, 11/2019) (MONRE 2020).

Water environmental pollution in many craft villages has become more and more serious. Some types of craft villages, especially recycled waste craft villages, are also causing serious water environmental pollution, directly affecting the health of a large part of people in these areas and surrounding areas. This is partly due to expansion of production without waste water treatment plants.

The volume and characteristics of waste water in craft villages depends on production technologies and materials. Food processing, husbandry and slaughtering, silk weaving and dyeing require high volumes of water and discharge high volumes of wastewater containing a high concentration of organic matters. While some crafts such as recycling, metal fine art, copper casting do not require high volumes of water they discharge toxic matters such as chemicals, acids, metal salt, Cyanide and heavy metal such as $\mathrm{Hg}, \mathrm{Pb}, \mathrm{Cr}, \mathrm{Zn}, \mathrm{Cu}$, etc.

Based on published data of Vietnam Environment Administration, Ministry of Natural Resources and Environment and Environment and Natural Resources Department of Provinces in Vietnam from 2014-2019, Vietnam's water environmental pollution in craft villages of Vietnam is facing great challenges in the coming years, such as: 


\subsection{Surface water pollution in craft villages}

Surface water in local areas, especially in craft villages in Red River basin, Cau River basin in the North and Dong Nai basin in the South has been polluted due to the impact of waste water.

- Surface water is seriously polluted by organic matters. Water quality of the ponds, lakes, canals and rivers of these villages is seriously polluted and in some areas the pollution has reached alarming levels. The activities of craft villages release wastewater containing high concentrations of organic matter and leads to high volumes of COD, BOD5 ,NH4+, Coliforms, and colour that go beyond Vietnamese National Standards (TCVN).

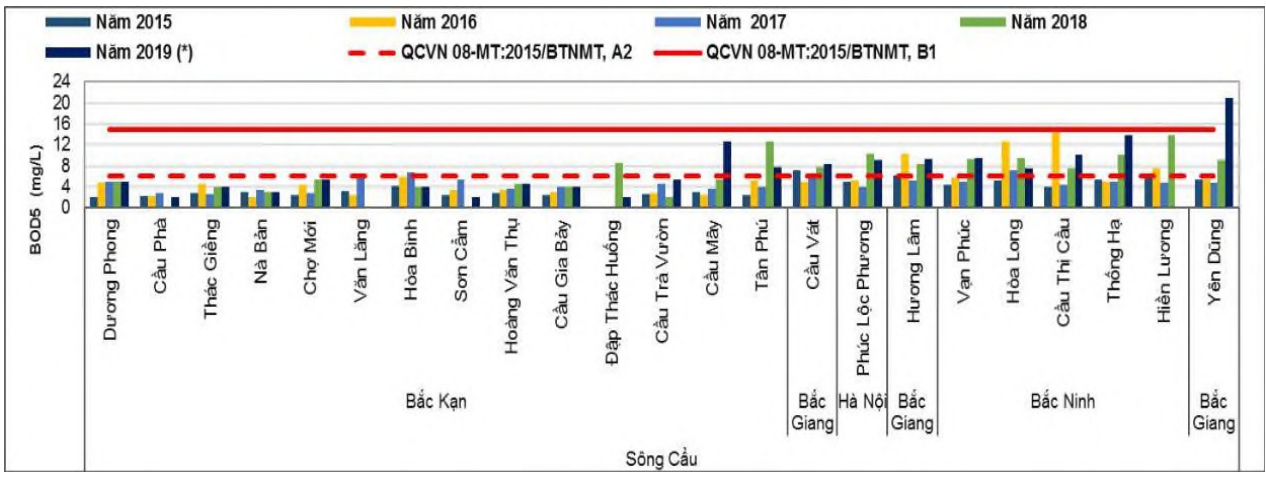

Fig. 3. BOD5 ( $\mathrm{mg} \mathrm{O} / \mathrm{L}$ ) value ratio at the monitoring points on Cau River, in the Cau River basins in Vietnam during 2016-2019 (Source: Vietnam Environment Administration, Ministry of Natural Resources and Environment, 11/ 2019) (MONRE 2020).

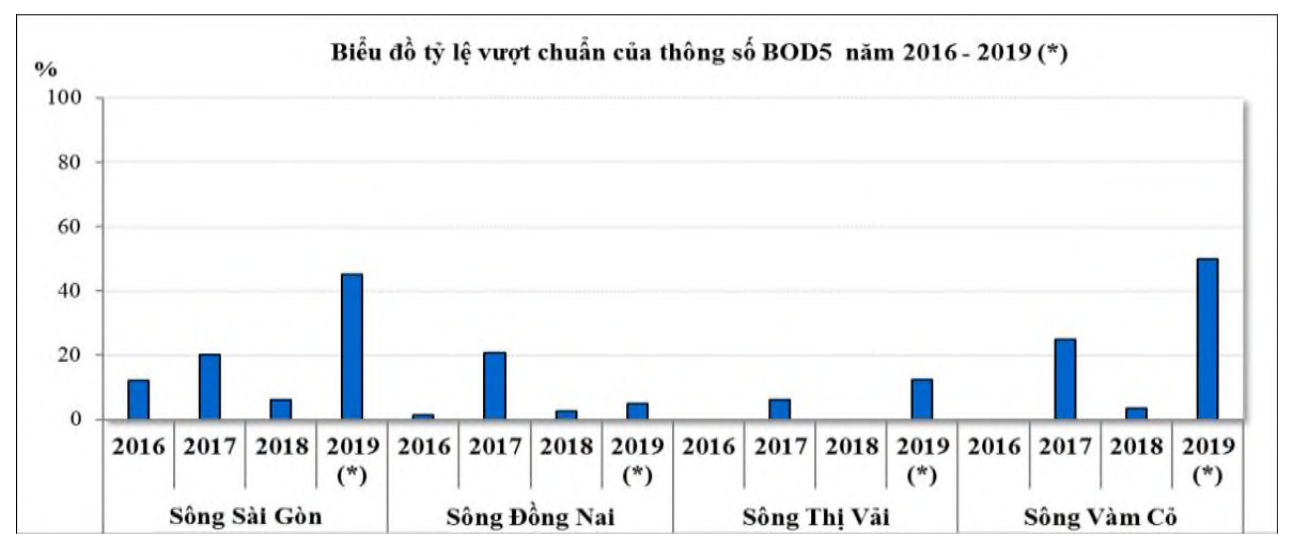

Fig. 4. BOD5 (mg O2/L) value value exceeds the standard on Dong Nai river basin period 20162019 (Source: Vietnam Environment Administration, Ministry of Natural Resources and Environment, 11/ 2019) (MONRE 2020). 


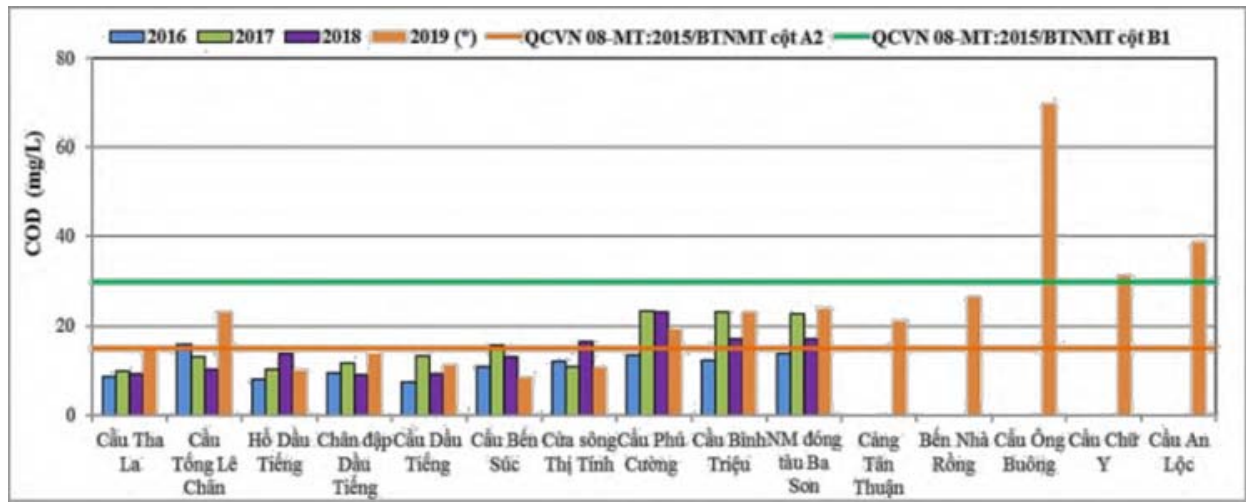

Fig. 5. COD (chemical oxygen demand) value ratio at the monitoring points on Sai Gon River during 2016-2019 (Source: Vietnam Environment Administration, Ministry of Natural Resources and Environment, 11/ 2019) (MONRE 2020).

- Recycling activities are usually implemented by craft villages. Among these craft villages, there are more than 100 recycling craft villages, with $80 \%$ is metal recycling villages, the others are paper and plastic recycling. The properties of these recycling villages are: (i) not regulated by any specific laws and regulations; (ii) informal sector that uses rudimentary, simple and backward technologies that do not meet technical and environmental protection requirement; (iii) low quality and production efficiency; and (iv) dealing mostly with the domestic scrap, which is normally polluted and not well-sorted. (Hai H.T., Quang N.D., Thang N.T., Nam N.H. (2020). In particular, many unsanitary landfills and incinerators have not yet met environmental technical standards, causing environmental pollution due to the generation of secondary wastes such as wastewater, gaseous emissions and solid waste.

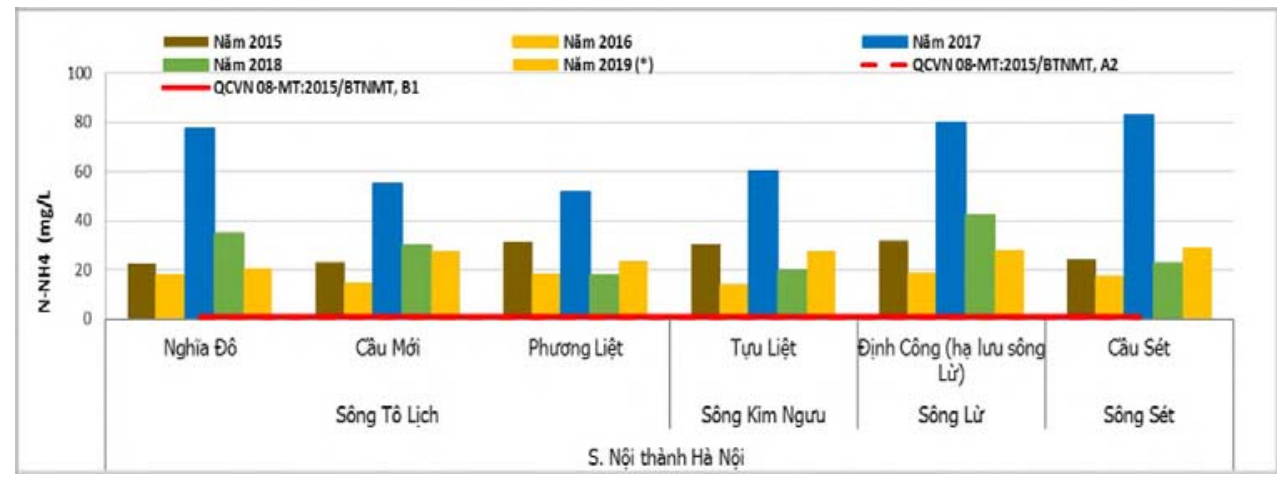

Fig. 6. $\mathrm{N}-\mathrm{NH} 4^{+}$value ratio at the monitoring points in rivers in Hanoi during 2015-2019 (Source: Vietnam Environment Administration, Ministry of Natural Resources and Environment, 11/2019) (MONRE 2020).

\subsection{Ground water pollution in craft villages}

Production activities in craft villages also affect the quality of ground water. Ground water of these craft villages has been polluted, with some areas seriously polluted: NH4+ concentrations of ground water of the Duong Lieu starch processing village and the Phung Xa dyeing and weaving village are very high (18.46 mg/land $17.75 \mathrm{mg} / \mathrm{l}$ respectively); $\mathrm{H} 2 \mathrm{~S}$ concentration in the ground water of the Tan Phu Dong starch processing, Dong Thap 
reaches up to $28.40 \mathrm{mg} / \mathrm{l}$. Coliforms of groundwater of craft villages is 2-100 times higher than Vietnamese National Standards (TCVN) (MONRO 2008).

\section{The shortcomings and limitations of management and implementing the regulations related to water environmental protection in craft villages of Vietnam}

In recent years, craft village environment has emerged as a hot and pressing issue. In parallel with the increase in the number and production types of craft villages, environmental pollution has also increased beyond the control of the authorities. In recognition of the issues, water environmental protection in craft village has been stipulated in legal documents such as: Vietnam Agenda 21 (The "Strategic Orientation for Sustainable Development in Vietnam" was issued by Decision No. 153/2004/QD-TTg of Prime Minister on 17 August 2004); the Vietnam Sustainable Development Strategy for 2011-2020 (was issued by Decision No. 432/QD-TTg of Prime Minister on April 12, 2012); The strategy for protecting the national environment by 2020, and the orientation towards 2030 (was issued by Decision No. 1216/QD-TTg of Prime Minister on September 05, 2012); Law on enviromental protection 2014 and legal documents detailing the Law on Environmental Protection of Ministries and People's Committees of provinces. These legal documents set out roles and responsibilities of stakeholders from central to local levels in environmental protection, especially water environmental protection of craft villages.

Based on 10 years of implementation, the mechanism management and legal framework for water environmental protection in craft villages of Vietnam shows that, besides some positive results, the laws has revealed the shortcomings and limitations such as:

- As about mentioned, unlike many countries in the world, craft villages in Vietnam are not only associated with the preservation of cultural values but also exist as industrial clusters. Craft villages differ from other industrial production and sectors by their diverse production types and development scales as well as their own characteristics. However, up to now, there has not been any legal documents on water environmental protection in craft village specific to production types of craft villages;

- The mechanism and policy water environmental protection in craft villages not appropriate and synchronized with requirements of craft villages development. The legal documents re those for general production type, leading to difficulties in applying to pecific craft villages. For example, according to Art.7, For example, according to Art.7, Circular No. 46/2011/TT-BTNMT providing for the environmental protection of craft villages, all establishments in the craft village have their environmental impact assessment (EIA) reports, written environmental protection commitments and detailed or brief environmental protection schemes approved or certified by competent agencies; have applied noise, dust, temperature, exhaust gas and wastewater control and proper on -site treatment measures; sort, collect and manage solid wastes and hazardous wastes (if any) according to regulations; commit to observing regulations on financial contributions to environmental protection in general and waste treatment funds in particular; This fact shows that it is difficult to apply this requirement to craft villages because enterprises of craft villages which are conducted in the household are smallscale and those who are involved in these enterprises cannot afford therequired environmental treatment equipment. Therefore, it should be redefined what is craft village and set up mechanism environmental protection in general and water environmental protection in particular in craft villages;

- Although responsibilities are assigned to ministers, unclear and overlapping responsibilities on craft village environmental protection still exist among ministries and 
sectors and between ministries and officers at the local level. In addition, there are limited instances of inter-sectoral collaboration. The state management on craft villages has been assigned to two ministries, namely the Ministry of Agriculture and Rural Development (MARD) and the Ministry of Industry and Trade (MOIT). In terms of environmental management, the Ministry of Natural Resources and Environmen (MONRO) has been assigned to develop andadopt policies on national environmental protection including craft villages (MONRO 2008). However, collaboration between theseministries has been insufficient. There have been a number of overlaps inmanaging development of craft villages between the MARD and the MOIT. Based on Government's Decree No. 52/2018/ND-CP dated April 12,2018 on development of rural trade, this has led to the lack of guidelines and support for production and trade of craft villages to attain sustainable development and to adopt measures for environmental protection in general and water environmental protection in particular (MONRO 2020);

- Limitation in collaboration between environmental authorities at all levels.There is a lack of close collaboration between central and provincial, district, commune and village authorities in thoroughly disseminating policies and regulations from central to local levels and infacilitating the coordinated management roles of authorities. Due to the lack of collaboration between central and local levels, several policies and legal documents that are adopted at higher levels have not been implemented strickly in craft village. such as environmental fee for wastewater, punishment of water environmental violation at craftvillages (MONRO 2020).

- Based on principle "polluters must pay for environmental treatment, remediation, renovation and restoration", Decree 154/2016/ND-CP on environmental protection fee on wastewater was issued by the vietnamese Goverment. However, collection of wastewater fee in craft villages has not implemented strictly. The reason is that other domestic activities usually merge with production activities, hence, it is difficult to separate domestic wastewater and production wastewater to impose a fee. In addition, people are still poor, water sources are rain wate rand from wells, consequently, the collection of fee, which is basrd on water consumption is difficult.

\section{Conclusions}

Based on challenges of water environmental protection in craft villages of Vietnam, the shortcomings and limitations of management and implementing the regulations related to water environmental protection in craft villages which need to be amended and supplemented with suggestion the following recommendations are proposed:

- Regarding to improve policy and legal documents on water environmental protection in craft villages

In accordance with international practice, it should be redefined what is craft village. Therefore, traditional craft villages should be recognized only with national cultural traits. The remaining craft villages must be relocated into industrial parks, industrial complexes, husbandry zones or production zones outside the population areas according to Article 36 and Clause 4 of Article 46 of the Law on environmental protection.

The legal documents on water environmental protection in craft villages must be amended and supplemented with suggestions: (i) Assign detailed responsibilites to organisations and individuals on water environmental protection in craft village, , especially stipulate responsibilities of localities and sectors in craft villages (MONRE in collaboration with MARD, MOIT, and relevant ministries); (ii) Develop guidelines on calculating pollution volume per ton of product based on material balance in order to calculate pollution vol ume for calculating environmental protectionfees for wastewater; (ii) 
Develop guidelines on environmental parameters needed for water environment observation in craft villages and environmental standards; (iii) Stipulating detailed sanctions for water environmental protection violation in craft villages; (iv) Apply criteria for compliance with environmental protection such as the existence of wastewater collection and drainage facilities; (v) Develop incentive policies (rewards, preferential loans and fees) for enterprises that comply with water environmental protection requirements (vi) Develop policies on the participation of communities in water environmental protection of craft villages.

Currently there are 07 types of environmental permits and discharging sewage into water sources. These permits are related and linked, so it is necessary to consider and integrate 07 types of environmental permits and discharge wastewater into 01 environmental permit to reduce administrative procedures and reduce licensing costs for enterprises.

- Regarding to improve enforcement mechanism on water environmental protection in craft villages

Strengthen water environmental monitoring and water pollution source inventory, strengthen monitoring activities atexisting and newly founded craft village industrial zones. Require industrialzones of craft villages to establish wastewater treatment plants. osts for these activities can be allocated from the local environment budget and from enterprises

Apply economic tools such as environmental protection fee for wastewater in craft villages based on volume of product per day. Based on this, calculate the environmental protection fee for wastewater in the future.

Strengthen legal tools and request enterprises of craft villages to comply with regulations of water environmen tal protection. Violations in discharge wastewater leading to negative impacts oncommunity health and crops must be punished strickly according to the state and local regulations./.

\section{References}

1. Circular No. 46/2011/TT-BTNMT of Ministry of Natural Resources and Environment (MONRE) (Hanoi, 2011)

2. Circular No. 31/2016/TT-BTNMT of Ministry of Natural Resources and Environment (MONRE) (Hanoi,, 2016)

3. Decree $154 / 2016 / N D-C P$ on enviromental protection fee on wasterwater (Government of Vietnam, Hanoi, 2018)

4. Decree 52/2018/ND-CP on development of rural trades (Government of Vietnam, Hanoi, 2018)

5. H.T. Hai, N.D. Quang, N.T. Thang, N.H. Nam, Circular Economy: Global Perspective (Springer, Singapore, 2020) DOI: 10.1007/978-981-15-1052-6_22.

6. National state of environment 2008 Vietnam craft village environment (Ministry of Natural Resources and Environment (MONRE), Hanoi, 2008)

7. Five years Summary Report on enforcement of Law on Environment Protection 2014 (Ministry of Natural Resources and Environment (MONRE), Hanoi, 2020)

8. Prime Minister of Vietnam, Decision No. 153/2004/QD-TTg: Approval of the "Strategic Orientation for Sustainable Development in Vietnam" (Vietnam Agenda 21, Hanoi, 2004)

9. Decision No. 432/2012/QD-TTg: Approval of sustainable development strategy of Vietnam period 2011-2020 (Prime Minister of Vietnam, Hanoi, 2012) 
10. Decision No. 1216/2012/QD-TTg: Approval of national environmental protection strategy by 2020, with a vision toward 2030 (Prime Minister of Vietnam, Hanoi, 2012)

11. Vietnam Law and Legal Forum. Revised Law on Environmental Protection (2015)

12. Vietnamese National Assembly's Law Nr.55/2014/QH13 (2014) 